Research:

\title{
ANALYSIS BUDGET REALIZATION, PROSPECTIVE PROVIDER FOR THE FUTURE PROJECTS AT PT SERINDO
}

\author{
By: \\ MUHAMMAD NUR RIZQI \\ Lecturer at STIE Binaniaga Bogor
}

\begin{abstract}
Facing huge economic development and competition, a construction service company should have to be aware of it by implementing a good management to provide a good planning especially how to execute the future projects properly by re-evaluating the previous projects had been done. The objective of this research is to find out that the provider and the type of the project have influenced the realization of the company's budget. And to study whether the budget realization is a variable to measure the success of a project. The writer has applied a quantitative data refers to budget and budget realization. He has been using SPSS program version 11.5 to obtain the regression approach and distinctive test to evaluate the project conducted by the company. He has been applying a discriminatory measures to evaluate the provider which is providing a high profit to the company. Result of this research has declared that either SNS and Protelindo provider dealing with various projects of SITAC and CME has been influencing the budget realization of the company, and budget realization is considered as a predictor variable against the success of each project.
\end{abstract}

Keywords: budget realization, prospective provider for the future projects.

\section{INTRODUCTION}

The objective of the company which is in a competitive economics condition is to gain the profit as much as possible continuously and to maintain the longlife of the company itself. Reaching the goals of the company, it will always be trying to evolve the efficacy and efficiency of the job.

In order to ensure that the company has performed the strategy effectively and efficiently, the management has been implementing a control process which is controlling the budget spending. A budget is a directory to help the managers to focus on the operational or financial matters earlier to execute the control more effectively.

Accounting responsibility is an accountancy system which declares that it is the central of the company responsibility and guideline overall to determine the income and distinctive costs or expenses. Accounting responsibility is an authority given and the way how to be responsible for it by issuance the written reports. A good accounting report should have to determine or to give an authority clearly to regain the awareness of the people in charge. Such an authority and responsibility will ease the controlingl and to avoid any deviation occurred.

By implementing the best accountancy system will create a good controlling and measuring tool to evaluate the performance of the manager which is the fundamental measuring system. Responsibilities' report can be applied as the fundamental measurement to analyse and measure the manager's performance. Reporting accounting system is a method to control the cost. Cost which is in the reporting accountancy system connected to the manager's authority to consume the sources which should have to be converted as token sum of money and is considered as a cost. This reporting system is a method to control any cost where the managers could be able to spend the related cost properly.

PT Serindo is a subsidiary of Serin Telecom Corp. locates in Seoul Korea. PT Serindo is a telecommunication construction company. Recently there are some projects still running and are going to be completed soon. In order to find out the level of the success of the project and to measure the company's performance, then, a measurement system against the project executed as well as a budgeting system for the next projects should have to be established. Therefore, the realization of PT Serindo projects should have to evaluated properly. 


\section{LITERATURE REVIEW}

Cost Accounting is a specific process of recording, classifying, summarizing and providing a production cost and selling price of the product or service as well as evaluating it. (Mulyadi, 1999). Cost accounting is a branch of the accountancy as the tool of the management to monitor and record all cost transaction properly which is described as cost. (Supriyono, 1996).

Cost is an object recorded, classified, summarized and presented by cost accountancy. (Mulyadi, 1999). The central of the responsibility is a unit of an organization managed by a manager who is in charged to it. (Halim, 1993).

The Central of the responsibility is a department, section or a group which is operating under a supervision and an authority of a responsible manager. (Sugiri, 1994). It is an organization managed by a manager who is responsible for all the activities. (Antony and Govindarajan, 2004).

Concept of input, output and cost has been applied to explain the meaning of the efficacy and efficiency which is the performance criteria of the central of responsibility unit. Both terms have often been applied within their central of the responsibility units. When the central of responsibility unit $\mathrm{A}$ has gained a $80 \%$ efficiency, it explains that it is more (or less) efficienct than the other/competitor, the recent efficiency is more(or less) than the previous one, it is more(or less) efficient than the budget or it is more (or less) efficient than the central of responsibility unit $B$. The central of responsibility unit $A$ is more efficient than the central of responsibility unit $B(1)$ when it has been applying less quantity of its sources than $B$, but it has produced the same quantity of output or (2) when it has applied the same quantity of the sources but it has produced higher output. Most of the central of the responsibility units have been measuring the efficiency by comparing the actual cost with standard cost which is all the cost has to be defined within the output being measured.

Antony and Govindarajan (2004) defined that an efficiency is a ratio between output and input or a total output per unit against the input.

Most of the central of responsibility units have measured the efficiency by comparing the actual cost with the standard cost which is the cost has been defined within an output measured. Comparing to the efficiency which is being determined by the correlation of input and output, the efficacy refers to the correlation of the output of the central of responsibility unit and the related goals. The bigger the output contributed against the goals, the more effective unit is. Since it is very difficult to quantify either the goals or input, the effectiviness refers to subjective and nonanalytical terms.

The effectiveness and the effiency are connected; every central of the responsibility unit should have to be as effective and efficient as possible and the company has to achieve an optimum result. Antony and Govindarajan (2004) summarized that the central of responsibility unit would be efficient and effective if it were performing all the things properly.

Arens (2003) Effectiveness refers to accomplishment of objective, where efficiency refers to resources used to achieve those objectives. Komarudin (1994) defined that an effectiveness is a state which is supporting the leverage of either success or failure of the management in achieving thre goal of the company which has been determined.

A company is expected to be existent and developed properly. To gain the aforementioned expectation, the company is obliged to have a competitive superiority refers to a unique strategy. The strategy has disclosed the critical success factors to be achieved by the company. Those success factors are referring to the financial profit and non financial profit such as new product development, product quality, customer satisfaction. The companies that have been applying the aforementioned factors successfully will be able to keep up strategically with their competitive and superiority state. (Blocher, 2005).

The management controlling system is a tool to implement the strategy of the company. Every organization is having the same objective but different strategy to achieve it.

A strategy is a chain of planning to achieve the organization's goals. Antony and Govindarajan (2004) said that strategy has described a common direction how to achieve the goals. A well managed organization has one good strategy or more, though they are not disclosed explicitly.

The success of a company's in the competitive era is depending on the capability of the company to deal with any challenges coming up, by having a proper formulation in implementing the strategy is able to get along with the core competencies of the company. (Hax and Majluf, 1995). The empiric study of Covin (1990), refers to the type of the strategy implementation it is 
concluded that the company which is having a proactive strategy, innovation and confrontation ability against the competitors indicating a better performance rahter than the pasif one. Empiric study of Power (1982) and Waalewijn (1993) regarding the implementation of the strategy against the company's performance has concluded that the implementation of the strategy shows a positive influence to the improvement of the company's performance.

Concept of input, output and cost which had been spent, can explain the meaning of the efficiency and effectiveness of the company which both criteria are to evaluate the performance of the headquater of the company. Those aforementioned terms have been applied very often by the central of responsibility. When the central of responsibility unit A has $80 \%$ efficiency, it explains that it is more (or less) efficient than the competitor, it is more (or less) efficient than the previous one, it is more (or less) efficient than the budget or it is more (or less) efficient than the central of responsibility unit $\mathrm{B}$.

Efficiency is a ratio between output and input, or the total input per unit. The central of responsibility unit $A$ is more efficient than the central of responsibility unit $B$ (1) when it has consumed less total sources than unit B, but it has produced the same output as unit B, or (2) it has consumed about equal total sources to the unit B consumed, but it has produced bigger amount output rather than unit B produced. Most of the central of responsibility units have been measuring their efficiency by comparing the actual cost with standard cost which should be identified within the output measured.

Comparing to the efficiency which was defined by the connection of the input and the output, the efficacy was defined by the correlation between the output of the central of responsibility unit and the objectives. The more the output has been contributed against the goals of the unit, the better effectiveness of the unit has. Since it is very difficult to quantify the goal and the output, therefore, the effectivreness is inclined to be described within the subjective term and non-analitical term.

The efficiency and effectiveness are interconnected and every central of responsibility unit must be effective and efficient where the organization itself has been obliged to achieve an optimum result. A central of responsibility unit which is performing the tasks and consuming the lowest total sources is efficient, but when the output has failed to contribute the expected achievement of the organization, it explains that the central of responsibility unit is not effective. According to Anthony and Govindarajan (2004), a central of responsibility unit is efficient and effective when it has conducted properly.

\section{RESEARCH METHODOLOGY}

This research has been applying the regression approach to see whether or not there is a significant influence of the providers occurred against the budget realization. The second regression is to find out a significant influence of the project type against the budget realization. The researcher has applied a deviation test to examine the differences of budget realization between NSN provider and protelindo.

The researcher is going to explain about the discrimination of the providers to find out which provider that has provided the most profit for the company. The researcher has examined the project of Protelindo - mobile 8 in Makassar at 12 sites; the project Three of Nokia Siemens Network in Semarang and Yogyakarta at 12 sites.

\section{Data Analysis Technique}

1. Qualitative data analysis

is an analysis technique to describe a qualitative data which is going to be analyzed properly.

2. Quantitative data analysis

the researcher has been applying the future budget data and the data of the payment for all the projects in 2007 . The following is the formulation to obtain the effectiveness and efficiency value: 


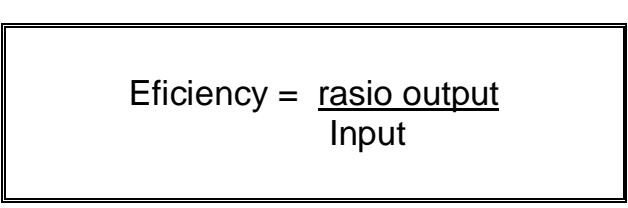

or

$$
\text { Eficiency }=\frac{\text { total output }}{\text { Input }}
$$

but

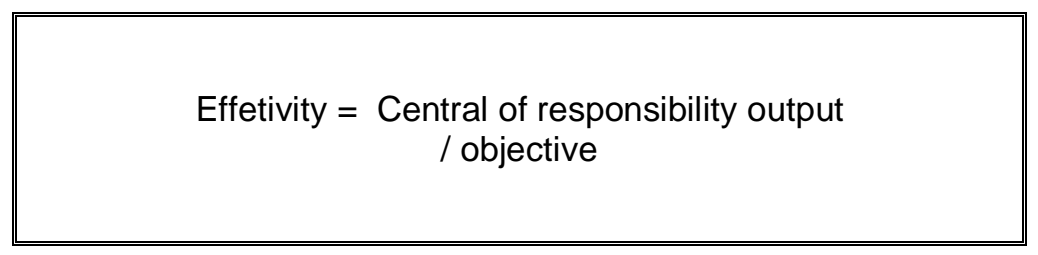

3. Statistics Analysis

Data analysis of this research aims to recognize the truth of the hypothesis - research hypothesis.

\section{RESULT AND EXPLANATION}

The organization stucture of PT Serindo is considered to be far from good because it is too simple and has not yet differentiated the operational functions clearly and properly.

Based on the research and the analysis, it is concluded that the organization structure of PT Serindo Construction should have to be redesigned in order to be able to implement the accounting responsibility.

According to the aforementioned budget, it explains that the department of logistics has not yet been coordinating with the production to implement the budget refers to daily workers payment. Daily workers wages should have to be considered as an important fix cost, even though the purchase order did not mention yet any specific value about it (civil).

\section{Reporting Analysis}

Reporting system is a very important thing to be conducted as the management will get an accurate and a quick information, so that the management could evaluate and perform a corrective action before the bigger problem coming up. That is why a reporting about project responsibility should have to indicate the comparison between budget and the budget realization in detail.

The differences between the budget and the budget realization of the project cost explaining the performance of the company itself. Generally, when the realization of the budget is > the budget refers to non satisfied company's performance, but when the budget is $>$ its realization refers to satisfied company's performance. Nevertheless, even the budget realization is $>$ its budget, it does not always mean that the company's performance is bad, because, there are some deviation matters along with other factors have been coming up, such as deviation standard occurred, material price increased drastically, unqualified supervisors on the job or unqualified daily workers which is jeopardizing the time schedule.

According to the related report of the responsibility, preparing the budget for the next project could be detemined in a proper way. The director is able to evaluate whether or not the company performance is effective, this kind of report could motivate every central of responsibility unit to improve their performance. Herebelow is the data about both projects, SITAC and CME conducted by PT Serindo which is showing the total budget value, the total of budget realization and the 
effectiviness value of the aforementioned projects both Protelindo and NSN provider. The researcher has been applying the regression analysis as a tool to examine the correlation between the type of the projects and the provider; the type of the projects and budget realization; the provider and the budget realization, but the researcher has been applying a discrimination test to recognize who the best provider is.

Table 1. Budgeting Realization Effectivity - Eficiency SITAC by Protelindo provider

\begin{tabular}{|c|c|c|c|}
\hline Project & $\begin{array}{c}\text { Production budget } \\
\text { (in rupiah) }\end{array}$ & $\begin{array}{c}\text { Realization of } \\
\text { production budget } \\
\text { (in rupiah) }\end{array}$ & $\begin{array}{c}\text { Effectivity } \\
\text { Eficiency }\end{array}$ \\
\hline 1 & $47,500,000$ & $42,275,000$ & 0,90 \\
\hline 2 & $46,800,000$ & $42,120,000$ & 0,88 \\
\hline 3 & $46,100,000$ & $41,951,000$ & 0,92 \\
\hline 4 & $46,000,000$ & $41,860,000$ & 0,89 \\
\hline 5 & $47,500,000$ & $44,650,000$ & 0,93 \\
\hline 6 & $45,500,000$ & $40,495,000$ & 0,92 \\
\hline 7 & $47,000,000$ & $41,830,000$ & 0,92 \\
\hline 8 & $46,000,000$ & $42,780,000$ & 0,92 \\
\hline 9 & $46,500,000$ & $43,245,000$ & 0,90 \\
\hline 10 & $47,000,000$ & $43,710,000$ & 0,91 \\
\hline 11 & $45,000,000$ & $40,950,000$ & 0,98 \\
\hline 12 & $46,000,000$ & $43,240,000$ & 0,98 \\
\hline
\end{tabular}

Source : Internal report,

Table 2. Budgeting Realization Effectivity - Eficiency CME by Protelindo provider

\begin{tabular}{|c|c|c|c|}
\hline Project & $\begin{array}{c}\text { Production } \\
\text { budget (in } \\
\text { rupiah) }\end{array}$ & $\begin{array}{c}\text { Realization of } \\
\text { production budget } \\
\text { (in rupiah) }\end{array}$ & $\begin{array}{c}\text { Effectivity - } \\
\text { Eficiency }\end{array}$ \\
\hline 1 & $289,200,851$ & $257,388,757$ & 0,89 \\
\hline 2 & $289,200,851$ & $260,280,766$ & 0,90 \\
\hline 3 & $289,200,851$ & $263,172,774$ & 0,91 \\
\hline 4 & $289,200,851$ & 263172,774 & 0,91 \\
\hline 5 & $289,200,851$ & $271,848,799$ & 0,94 \\
\hline 6 & $299,872,851$ & $266,886,837$ & 0,89 \\
\hline 7 & $299,872,851$ & $266,886,837$ & 0,89 \\
\hline 8 & $299,872,851$ & $278,881,751$ & 0,93 \\
\hline 9 & $299,872,851$ & $278,881,750$ & 0,93 \\
\hline 10 & $289,200,851$ & $260,280,766$ & 0,90 \\
\hline 11 & $289,200,851$ & $263,172,774$ & 0,91 \\
\hline 12 & $289,200,851$ & $271,848,799$ & 0,94 \\
\hline
\end{tabular}

Source : Internal report,

Table 3. Budgeting Realization Effectivity - Eficiency SITAC by NSN provider

\begin{tabular}{|c|c|c|c|}
\hline Project & $\begin{array}{c}\text { Production } \\
\text { budget (in } \\
\text { rupiah) }\end{array}$ & $\begin{array}{c}\text { Realization of } \\
\text { production budget } \\
\text { (in rupiah) }\end{array}$ & $\begin{array}{c}\text { Effectivity - } \\
\text { Eficiency }\end{array}$ \\
\hline 1 & $35,800,000$ & $35,800,000$ & 1,00 \\
\hline 2 & $37,700,000$ & $31,300,000$ & 0,83 \\
\hline 3 & $35,800,000$ & $32,250,000$ & 0,90 \\
\hline 4 & $35,800,000$ & $28,300,000$ & 0,79 \\
\hline 5 & $35,800,000$ & $32,220,000$ & 0,90 \\
\hline
\end{tabular}

Muhammad Nur Rizqi: Analysis Budget Realization, Prospective Provider for the Future Projects at PT. Serindo 


\begin{tabular}{|c|c|c|c|}
\hline Project & $\begin{array}{c}\text { Production } \\
\text { budget (in } \\
\text { rupiah) }\end{array}$ & $\begin{array}{c}\text { Realization of } \\
\text { production budget } \\
\text { (in rupiah) }\end{array}$ & $\begin{array}{c}\text { Effectivity - } \\
\text { Eficiency }\end{array}$ \\
\hline 6 & $35,800,000$ & $35,800,000$ & 1,00 \\
\hline 7 & $37,700,000$ & $33,555,000$ & 0,89 \\
\hline 8 & $36,700,000$ & $33,050,000$ & 0,90 \\
\hline 9 & $36,700,000$ & $33,050,000$ & 0,90 \\
\hline 10 & $36,700,000$ & $33,400,000$ & 0,91 \\
\hline 11 & $36,700,000$ & $33,764,000$ & 0,92 \\
\hline 12 & $37,700,000$ & $33,175,000$ & 0,88 \\
\hline
\end{tabular}

Source : Internal report,

Table 4. Budgeting Realization Effectivity - Eficiency CME by NSN provider

\begin{tabular}{|c|c|c|c|}
\hline Project & $\begin{array}{c}\text { Production } \\
\text { budget (in } \\
\text { rupiah) }\end{array}$ & $\begin{array}{c}\text { Realization of } \\
\text { production budget } \\
\text { (in rupiah) }\end{array}$ & $\begin{array}{c}\text { Effectivity - } \\
\text { Eficiency }\end{array}$ \\
\hline 1 & $176,746,340$ & $164,374,096$ & 0,93 \\
\hline 2 & $176,746,340$ & $169,676,486$ & 0,96 \\
\hline 3 & $176,746,340$ & $162,606,633$ & 0,92 \\
\hline 4 & $176,746,340$ & $162,606,633$ & 0,92 \\
\hline 5 & $176,746,340$ & $159,586,340$ & 0,90 \\
\hline 6 & $176,746,340$ & $160,205,546$ & 0,91 \\
\hline 7 & $128,032,600$ & $126,752,274$ & 0,99 \\
\hline 8 & $128,032,600$ & $120,350,644$ & 0,94 \\
\hline 9 & $128,032,600$ & $128,032,600$ & 1,00 \\
\hline 10 & $152,032,600$ & $148,991,948$ & 0,98 \\
\hline 11 & $152,032,600$ & $145,951,296$ & 0,96 \\
\hline 12 & $152,032,600$ & $141,390,318$ & 0,93 \\
\hline
\end{tabular}

Source : Internal report,

Regarding the efficacy and efficiency value of SITAC job at NSN project which is similar with Protelindo project. The more people included within the scope of the project, the bigger budget should have to be prepared. But, it could not be stated as a fixed indicator since the total amount of the people compensation is depending on the negotiation occurred between Sitas team and chief of local people. Reffering to the table of CME, determining the aforementioned budget is depending on the type of BTS executed, the smallest amount of the budget refers to BTS of $45 \mathrm{~m}$ height, then the bigger one refers to BTS project of $54 \mathrm{~m}$ height, and the biggest amount refers to BTS of $64 \mathrm{~m}$ height.

Table 5. Correlations project items between provider and realization Correlations

\begin{tabular}{|c|c|c|c|c|}
\hline & & jenis proyek & PRO & Realisasi \\
\hline \multirow[t]{3}{*}{ jenis proyek } & Pearson Correlation & 1.000 & $.894(* *)$ & -.101 \\
\hline & Sig. (2-tailed) & & .000 & .493 \\
\hline & $\mathrm{N}$ & 48 & 48 & 48 \\
\hline \multirow[t]{3}{*}{ PRO } & Pearson Correlation & $.894\left({ }^{\star *}\right)$ & 1.000 & $.334\left(^{*}\right)$ \\
\hline & Sig. (2-tailed) & .000 & . & .020 \\
\hline & $\mathrm{N}$ & 48 & 48 & 48 \\
\hline \multirow[t]{3}{*}{ realisasi } & Pearson Correlation & -.101 & $.334\left(^{*}\right)$ & 1.000 \\
\hline & Sig. (2-tailed) & .493 & .020 & . \\
\hline & $\mathrm{N}$ & 48 & 48 & 48 \\
\hline
\end{tabular}

* Correlation is significant at the 0.05 level (2-tailed). 
Table 6. Independent samples test

Independent Samples Test

\begin{tabular}{|c|c|c|c|c|c|c|c|c|c|c|}
\hline & \multicolumn{2}{|c|}{$\begin{array}{l}\text { Levene's Test for } \\
\text { Equality of Variances }\end{array}$} & \multicolumn{7}{|c|}{ t-test for Equality of Means } \\
\hline & & \multirow[b]{2}{*}{$\mathrm{F}$} & \multirow[b]{2}{*}{ Sig. } & \multirow[b]{2}{*}{$t$} & \multirow[b]{2}{*}{ df } & \multirow[b]{2}{*}{ Sig. (2-tailed) } & \multirow{2}{*}{$\begin{array}{c}\text { Mean } \\
\text { Difference }\end{array}$} & \multirow{2}{*}{$\begin{array}{l}\text { Std. Error } \\
\text { Difference }\end{array}$} & \multicolumn{2}{|c|}{$\begin{array}{l}95 \% \text { Confidence } \\
\text { Interval of the } \\
\text { Difference }\end{array}$} \\
\hline & & & & & & & & & Lower & Upper \\
\hline realisasi & $\begin{array}{l}\text { Equal variances } \\
\text { assumed }\end{array}$ & 435.978 & .000 & -2.400 & 46 & .020 & -63567524 & 26481020 & $-1.2 E+08$ & $-1.0 E+07$ \\
\hline & $\begin{array}{l}\text { Equal variances } \\
\text { not assumed }\end{array}$ & & & -2.400 & 34.871 & .022 & -63567524 & 26481020 & $-1.2 E+08$ & -9801087 \\
\hline
\end{tabular}

On the table 5 aformentioned, it explains about the correlation between the type of the project variable and the realization variable which is the correlation coefficient of Pearson $r=-101$ and the probability $=0.493$, explaining that there is not any significant correlation between both variables. But, referring to the correlation between provider variable and the realization variable, Pearson correlation coefficient value $r=0.344$ and the probability $=0.02$, explaining that there is a significant correlation between both variables. Furthermore, referring to the correlation between the type of the project variable and the provider variable, there is a very significant correlation which is pearson coefficient $r=0.894$ and the probability $=0.00$.

On the table 6 shows the independent T test of realization showing an assumption that the variants are homogen/ same which is Fcalculated is 435,978 and the significant value is 0.00 meaning the data is homogen. It has been determined that when Fcalculated is < Ftable or the significant value $=>0,05$, the data is homogen. On the Budget realization which is t calculated $=$ 2.40 , the degree of independence $=46$, average differences $=63,567,523.7$, failure standard $=$ $26,481,020$ and the significant value $=0.02$ which is explaining that there is a different budget realization between NSN provider and Protelindo.

Table 7 .

The discriminant between NSN and Protelindo

Classification Function Coefficients

\begin{tabular}{|c|c|c|}
\hline & \multicolumn{2}{|c|}{ PRO } \\
\hline & provider NSN & $\begin{array}{l}\text { provider } \\
\text { Protelindo }\end{array}$ \\
\hline realisasi & 1.082E-08 & 1.838E-08 \\
\hline (Constant) & -1.186 & -2.114 \\
\hline
\end{tabular}

Fisher's linear discriminant functions

According to the table above, the equation are:

NSN $\quad=-1.186+1.08$, while

Protelindo $=-2.114+1.8$

The conclusion that Protelindo Project makes profit bigger than NSN.

\section{CONCLUSION AND SUGGESTION}

\section{Conclusion}

According to the research about PT. SERINDO project realization. Author can conclude below:

a. Each provider; NSN and protelindo, both are influenced the budget that assigned by management.

b. Both project type ; SITAC and CME are not influenced the budget realization.

c. Budget realization is variable predictor for diskriminant test, and variable measurement of success. 


\section{Suggestion}

If the company just have limited money for many project; NSN and Protelindo at the same time, its better that company choose Protelindo project only. Because Protelindo project gives profit more than NSN, that proved by discriminant table.

Managerial implications

The author justifies the statistics calculation results, that appropriate with realization in every project. The fact that, there is almost no problem occurred at protelindo project in makasar even SITAC nor CME project. At NSN project there is different condition, almost every cities known well money such as in Jepara, Kendal and Yogyakarta. That's why, PT Serindo have to prepare variable cost more than Protelindo Project.

\section{REFERENCES}

Agustina Santoso, Eka. 2004. "Peranan Informasi Akuntansi Pertanggungjawaban dalam Penilain Kinerja Manajer Pusat Laba (Studi Kasus pada PT PLN Persero Distribusi Jawa Barat dan Banten)," UNIKOM, Bandung.

Anthony, Robert N, and Vijay Govindarajan. 2004. Management Controll System, Eleventh Edition, McGraw Hill.

Ardiansyah Purwanti, Agnes. 2006. "Analisis Akuntansi Pertanggungjawaban Biaya untuk Menilai Kinerja Manajer Produksi pada PT. Perkebunan Nusantara X (Persero) PG Tjoekir Jombang" Univ Merdeka Malang.

Blocher. Edward J, Kung H Chen, Gary Cokins, Thomas W Li1n. 2005. Cost Management; A Strategic Emphasis, Boston Mc Graw Hill, Irwin.

Covin. JG, Covin. TJ. 1990. "Competitive Aggressiveness, Environmental Context and Small Firm Perfomance, Enterpreneurship Theory and Practice". Summer. Vol 4.

Hax. AC., and N.S. Majluf. 1995. The Strategy : Concept and Process, A Pragmatic Approach. Saddle River, New Jersey, Prentice Hall Inc.

Halim, dan Supomo 1993. Akuntansi Biaya : Penentuan Harga Pokok dan Pengendalian Biaya. Yogyakarta YKPN.

Iswahyudi Dian 2000. "Analyse Applying of Responsibility Accounting as Means of Controller of Production Cost and Assessment of Production Manager Performance."

Kusmayadi, Dedi dan Kartawan. 2007. "Pengaruh Penerapan Akuntansi Pertanggungjawaban dan Implementasi Strategi terhadap Kinerja Perusahaan (Survey pada Perusahaan Manufaktur Aneka Industry di BEJ)", Univ Siliwangi.

Machfoedz, Mas'ud . 1992. Akuntansi Manajemen, Yogyakarta BPFE.

Mujiwati, Eryanti. 2004. "Peranan Penerapan Akuntansi Pertanggungjawaban dalam Menunjang Efektifitas Kinerja Manajer Pusat Biaya Kebijakan (Studi Pasus pada KPSBU Lembang)", UNIKOM, Bandung.

Mulyadi, 1999. Akuntansi Biaya: Penentuan Harga Pokok dan Pengendalian Biaya. Yogyakarta BPFE UGM.

Powell. T.C, 1992. "Strategic Planning as Competitive Advantage": Strategic Management Journal. Oktober. Vol 46, 
Reed, Anita. 2002. "Predicting Change in Management Accounting System", Journal of Management Accounting Research. Vol 8.

Sandra Asmara Dewi. 1998. "Evaluasi Akuntansi Pertanggungjawaban sebagai Alat Pengendalian Biaya Produksi pada PT Bigenindo Nusantara Jakarta", Univ Merdeka Malang,

Simangunsong, M.P 1996. Pelajaran Akuntansi Tingkat Dasar I dan II, Cetakan 24, Karya Utama

Sugiri, Slamet. 1994. Akuntansi Manajemen Sebuah Pengantar. Yogyakarta UPP AMP YKPN.

Supriono, R.A.. 1999. Akuntansi Biaya; Pengumpulan Biaya Penentuan Harga Pokok, Edisi Kedua, BPFE, Yogyakarta.

1996. Akuntansi Biaya dan Akuntansi Manajemen untuk Teknologi Maju dan Globalisasi. Edisi Pertama, Yogyakarta BPFE UGM.

Waalewijn. P., and P. Segaar 1993. "Strategic Management the Key to Profitability in Small Companies" : Long Range Planning, April Vol 4. 
The Accounting Journal of BINANIAGA Vol. 01, No. 1, 2016

ISSN: 2527 - 4309

This page intentionally be emptied.

Muhammad Nur Rizqi: Analysis Budget Realization, Prospective Provider for the Future

Projects at PT. Serindo

Page : 10 